UDC 1 Vedenski A. I.

82.09

https://doi.org/10.18485/ms zmss.2021.100.26

\title{
Корнелия Ичин
}

Филологический факультет Университета в Белграде

kornelijaicin@gmail.com

\section{Kornelija Ičin}

University of Belgrade, Faculty of Philology

kornelijaicin@gmail.com

ПРОЛЕГОМЕНЫ К НЕКОТОРОМУ КОЛИЧЕСТВУ РАЗГОВОРОВ А. ВВЕДЕНСКОГО

\author{
PROLEGOMENON TO THE A. VVEDENSKY'S \\ CERTAIN QUANTITY OF CONVERSATIONS
}

В статье исследуется логика мышления Введенского, отметающего аристотелевскую логику и сомневающегося в возможности языкового определения бытия. «Поэтическая критика разума» Введенского показана на примере Некоторого количества разговоров, где раскрываются более глубокие связи между словами, чем заданные логическим мышлением. Представлена новая модель коммуникации, построенная не на отношении субъект - субъект, а на отношении субъекта к объектам здешнего мира, таким, как небесные светила, камни, горы, море, рыбы, птицы, насекомые, деревья.

Ключевые слова: А. Введенский, Некоторое количество разговоров, критика силлогизма, непонимание, время.

This paper discusses the A. Vvedensky's logic of thinking, which relies on Aristotel's logic, doubts the possibillity of linguistic determination of beings and enters the field of misconstruction. A. Vvedensky's "Poetic critique of reason" is shown on the example of the work of Certain Quantity of Conversatons, where even deeper connections between words are revealed than those determined by logical thinking. A new model of communication is presented, not based on the subject-object relationship, but on the subject's relationship to the objects of this world, such as celestial lights, rocks, mountains, sea, fish, birds, insects, trees.

Keywords: A. Vvedensky, Certain Quantity of Conversations, critique of syllogisms, misconstruction, time.

Некоторое количество разговоров (1936-1937) - произведение Введенского, в котором он исследует логику нашего мышления, толкует нашу сознательную и несознательную деятельность. Несознательная часть на- 
шего существования представлена снами, о чем говорит и подзаголовок «начисто переделанный темник» (темник - книга толкований снов). Введенский, усомнившийся в аристотелевской логике и в «понятности» мира, двигается к более глубоким мыслительным процессам человека.

Творческие устремления поэта, направленные на открытие иной логики связи между мгновениями и новых законов мироздания, которые основывались на иных взаимоотношениях между Временем, Смертью и Богом, привели к тому, что его персонажи зачастую одновременно являются живыми и мертвыми, жертвами и палачами, зрителями и участниками, они одновременно движутся в двух направлениях-смыслах, раскрывая и смысл, и бессмыслицу.

Гибридное сочетание противоречивых смыслов в стихах Введенского отмечал и Я. Друскин в своих дневниках 1944 года: «О стихах Введенского: в каждой фразе главное направление мысли и погрешность. Погрешность здесь материализована: словом, нарушающим смысл главного направления» (Друскин 1999: 205). Не случайно понятие «погрешности» в творчестве Введенского связывается с теорией «прибавочного элемента» Малевича, именуемого «бациллой», «прививкой», «возбудителем», с помощью которого супрематист пытался объяснить эволюцию нового искусства 1 . Эту противоречивость текстов Введенского по-другому сформулировал В. Подорога. По его мнению, сила текстов обэриутов (в том числе и Введенского) заключается в том, что «они нам показывают со всей ясностью линию демаркации между чтением и пониманием» (Беседа с В. Подорогой 1993: 140). Если философское мышление исследует «существование поэтического произведения в “настоящем”, во время чтения» (Там же: 141), т. е. становление его во время чтения, то возникает вопрос, претерпеваем ли и мы становление в тексте во время чтения или наше становление происходит в зазоре между чтением и пониманием? Об этом Введенский на «своем языке» писал в «Серой тетради»:

Наша человеческая логика и наш язык не соответствуют времени ни в каком, ни в элементарном, ни в сложном его понимании. Наша логика и наш язык скользят по поверхности времени. Тем не менее, может быть, что-нибудь можно попробовать и написать, если и не о времени, не по поводу непонимания времени, то хотя бы попробовать установить те некоторые положения нашего поверхностного ощущения времени, и на основании их нам может стать ясным путь в смерть и в широкое непонимание. Если мы почувствуем дикое непонимание, то мы будем знать, что этому непониманию никто не сможет противопоставить ничего ясного. Горе нам, задумавшимся о времени. Но потом при разрастании этого непонимания тебе и мне станет ясно, что нету ни горя, ни нам, ни задумавшимся, ни времени (Введенский 1993, 2: 79).

1 Более подробно об этом см. в: Ичин 2019: 215-228. - Об прибавочном элементе у Малевича писал также М. Грыгар, ссылаясь на термин «прибавка» И. Павлова, который русский физиолог употреблял, когда говорил о прибавочном факторе речи (см.: Грыгар 2007: 301-324). Сходство концепции Малевича с современными нейробиологическими теориями искусства отмечает В. Гречко (см.: Гречко 2012: 89-102). 
Непонимание, о котором пишет Введенский, есть разрыв времени (мысли, языка), область бессмыслицы, выход за пределы понимаемого как очевидного ${ }^{2}$. Широкое непонимание означает регрессию в добытийное. С ним связаны как онтологические, так и логические и гносеологические вопросы. Только из этого, добытийного, можно вызвать мир Словом, «заставить» его быть, но уже на других (возможно, поэтических) основах. Примером такого мира могут послужить заключительные строки - эпилог в сочинении «Мир»: «На обоях человек, А на блюдечке четверг» (Введенский 1993, 1: 160). Не случайно Яков Друскин писал в 1969 году в своем дневнике, что «Мир» Введенского он ощущает «вполне экзистенциально», хотя «иероглиф последней строчки» он не может «не только определить, но и сказать о нем что-либо», так как чувствует, что «это последний предел мысли» (Друскин 2001: 455).

Введенский в своем творчестве посягает на понятия и их исходные логические обобщения, характеризуя их как «поэтическую критику разума», о чем сообщает в «Разговорах», записанных Л. Липавским в 1933-1934 годах:

Я усумнился, что, например, дом, дача и башня связываются и объединяются понятием «здание». Может быть, плечо надо связывать с четыре. Я делал это на практике, в поэзии, и тем доказывал. И я убедился в ложности прежних связей, но не могу сказать, какие должны быть новые. Я даже не знаю, должна ли быть одна система связей или их много. И у меня основное ощущение бессвязности мира и раздробленности времени. А так как это противоречит разуму, то значит разум не понимает мира (Липавский 1998: 186).

Иными словами, Введенский пытается раскрыть более глубокий смысл слова, раскрыть более глубокую связь между словами, чем та, которая автоматически выстраивается, скользя по поверхности обыденного словоупотребления. Его интересует не столько некоммуникабельность в отношениях человек - человек, как это в театре абсурда Ионеско и Беккета, сколько особенности отношения человека (лирического субъекта) к другим «объектам» здешнего мира, таким, как небесные светила, камни, горы, море, рыбы, птицы, насекомые, деревья 3 . Исследование связей между человеком и мирозданием приводит к существенным изменениям в поэтическом мире Введенского, отличающем его от всего до того написанного. Эти изменения касаются не только раскрытия новых, глубинных связей между словами, но прежде всего трансформации понятия времени, которая по-другому стала определять бытие человека и предметов в мире, чем

2 В. Руднев в статье «ОБЭРИУ» пишет, что «объединяло обэриутов главное - нетерпимость к обывательскому здравому смыслу и активная борьба с “реализмом". Реальность для них была в очищении подлинного таинственного смысла слова от шелухи его обыденных квазисмысловых наслоений» (Руднев 2017а: 445).

3 Отмечая в стихах Введенского установку поэта на отношения лирического «я» к другим объектам нашего мира, О. Ревзина пишет, что поэзия Введенского «подчеркнуто когнитивна, в ней отсутствует установка на коммуникативную функцию» (Ревзина 1978: 398). 
по сути привела к восприятию поэтического мира как абсурдного ${ }^{4}$ В. Руднев в своей книге Против Истины дает наиболее точное определение абсурда, которое применимо к творчеству Введенского:

Обыденный здравый смысл тяготеет к поверхностной реальности денотатов, абсурд тяготеет к глубинной реальности Реального. Поэтому бессмыслица глубже осмысленности. Она раскрывает связи, отсутствующие поверхностно, но присутствующие глубинно, так как все слова в языке связаны. Таким образом, абсурд - это не отсутствие смысла, а расширение и углубление смысла (Руднев 2017 b: 45-46).

Введенский, по-видимому, размышлял о новом уровне единства явлений в мире, задолго до ученых, описавших хаотические процессы (нестабильность, непредсказуемость, дробную размерность) в динамических системах. Свое ощущение нестабильности - «мерцания» мира, хаоса, раздробленности времени поэт воплощал в стихах, пытаясь ответить на вопрос о мире и человеке в мире, как, например, в стихотворении «Значенье моря» (ср.: «мы подумав будто трупы/показали небу крупы/море время сон одно / скажем падая на дно» - Введенский 1993, 1: 117) или в Некотором количестве разговоров, которые в данном случае нас прежде всего интересуют. Введенский создает апофатическую поэтику, основанную на отказе от понимания, на отрицании обыденных языково-смысловых связей, на минус-определении. Согласно поэту, такие «заумные» категории, как Бог, смерть и время не способен понять человеческий разум (ср.: «Что знаем о смерти мы люди» в тексте «Очевидец и крыса»; «Но где ж понять исчезновенье/И все ль мы смертны?» в пьеске Потец - Введенский 1993, 1: 176, 190), поэтому ничего утвердительного о них нельзя сказать 5 . Разочарованность в научном мышлении, отрицание логического понимания, сомнение в возможности языкового определения бытия - налицо в Некотором количестве разговоров ${ }^{6}$. Введенский разрушает логические законы, основанные на силлогизмах Аристотеля. Если силлогизм состоит из трех суждений (два из них - посылки, которые объединены общим (средним) термином, а третье - заключение), русский поэт в лице Троих из Разговоров проводит критику силлогизма.

4 Ср., напр.: «Я с временем не знаком, Увижу я его на ком? Как твое время потрогаю? Оно фикция, оно идеал. Был день? был. Была ночь? была», «Всё твое время веревка. Тянется, тянется. А обрежь, на руках останется» (Кругом возможно Бог); «Мне трудно, что я с минутами, меня они страшно запутали» («Мне жалко, что я не зверь...»); «Я думаю темя Проносится час С минутами теми На яблоке мчась» («Битва»); «Мы и не успели посмотреть минуту эту, А смотрите Бог, рыба и небо, исчез тот кусок» («Приглашение меня подумать»); «Он нас принимал за минуты» («Где. Когда»).

5 Об апофатической поэтике А. Введенского см. в: Татаринова 2011: 357-359.

6 По замечанию Г. Робертса, в Некотором количестве разговоров Введенский, «вместо того, чтобы утверждать, что слова и мысли реальны как конкретные предметы», исследует «идею о том, что реальный мир - вещи и люди - так же нереальны, как вербальные и ментальные явления» (Roberts 1997: 151). С другой стороны, Р. Милнер-Галланд в «бедности языка», о которой пишет Введенский в Некотором количестве разговоров, обнаруживает связь с философскими размышлениями Виттгенштейна о границе языка (Milner-Gulland 1984: 33). 
В начале первого из десяти разговоров, «Разговора о сумасшедшем доме», сразу демонстрируется разрушение мыслительных процессов, их деавтоматизация, создание тупиковой ситуации:

Перв ы й. Я знаю сумасшедший дом. Я видел сумасшедший дом.

В т о рой. Что ты говоришь? я ничего не знаю. Как он выглядит.

Тр е и й. Выглядит ли он? Кто видел сумасшедший дом.

Перв ый. Что в нем находится? Кто в нем живет.

Второй. Птицы в нем не живут. Часы в нем ходят.

Тре т й. Я знаю сумасшедший дом, там живут сумасшедшие.

(Введенский 1993, 1: 196)

В репликах-мыслях Первого и Второго разрушается привычная для нас модель построения диалога: информация Первого, в которой глаголы видеть и знать (ведать) отождествляются, не находит необходимого отклика, так как вопрос «Что ты говоришь?» является ложным следом продолжения разговора, погрешностью, о которой говорил Я. Друскин. В этом нас заверяют последовавшее за вопросом отрицание «я ничего не знаю», сопротивляющееся реплике Первого «Я знаю», и утвердительное предложение с вопросительным словом «как». Синтаксическая логика уже расшатана, и теперь Третий может усомниться в самой видимости сумасшедшего дома («Выглядит ли он?»), а также в существовании субъекта, который мог бы увидеть невидимое («Кто видел сумасшедший дом»). В реплике Третьего внимание переносится на вопросительное местоимение в изъявительном предложении, чем, по сути, акцентируется иная синтаксическая логика, разбивающая канон обыденного мышления. В продолжение обмена мыслями трое меняются местами: вместо Второго теперь Первый задается вопросом «Что в нем находится?», включает вопросительное местоимение «Кто» в ровную интонацию изъявительного предложения («Кто в нем живет»), оспаривая этим собственное начальное утверждение «Я знаю сумасшедший дом. Я видел сумасшедший дом». В ответ на вопрос-мысль Первого «Кто в нем живет» Второй дает апофатическое определение жизни в сумасшедшем доме: «Птицы в нем не живут», противопоставляя птицам (т. е. душам, как их изображали в разных мифологических представлениях) ход часов: «Часы в нем ходят». При этом важно указать также на противостояние статическому «находится» действующего «ходят», вышедших из общей семантической основы «ход», чем по сути демонстрируется погрешность, уводящая смысл в разные направления. Теперь в обмене мыслями очередь за Третьим, который берет на себя роль Первого и повторяет эхом первую часть его реплики: «Я знаю сумасшедший дом, там живут сумасшедшие». Итог первых реплик: в сумасшедшем доме ходят часы и живут сумасшедшие, т. е. часы отсчитывают время человека, напоминая ему о бренности, сумасшедшие живут с часами, отмеряющими их время. Другими словами, сумасшедший дом - это (сумасшедший) человек с часами, но без души-птицы, следовательно, без возможности преодолеть время и приобрести бессмертие (вечность). 
Как мы видим, уже в начальных репликах поэт заявил о своем намерении исследовать категорию времени и провести критику языка и его возможностей 7 . По справедливому замечанию В. Фещенко, Введенский «стремился посредством поэтического искусства проникнуть в новую реальность, неведомую классической рациональности» (Фещенко 2009: 243). Введенского занимает, прежде всего, непонимание, которое мыслится им как начало познания мира и себя в мире. Эту его позицию выражают и строки стихотворения «Приглашение меня подумать»: «Нам непонятное приятно, / Необъяснимое нам друг» (Введенский 1993, 1: 182). Об этом Введенский писал также в «Серой тетради»: «Если мы почувствуем дикое непонимание, то мы будем знать, что этому непониманию никто не сможет противопоставить ничего ясного» (Введенский 1993, 2: 79).

Все «разговоры» построены на обращении к мыслительным и языковым процессам человека 8 , все они демонстрируют неустойчивость этих процессов, а также раздробленность мира, созданного этими процессами. В работе Введенского с языком происходит то, что Вяч. Вс. Иванов назвал «семантическим экспериментом», устремленным на то, чтобы «представить смысл в совершенно новой, внелогической перспективе, путем ухода от сложившихся семантических механизмов, нарушения семантических основ языка» (Иванов 2000: 277). Разбивая языковую, умозаключительную и причинно-следственную логику, Введенский измельчает мир до неподвижности, в этом мире перестают действовать законы времени - до и после, прошлого и будущего. В этом мире существуют мгновения бытия, вокруг которых все вращается и которые создают лейтмотивные повторы: «Уважай бедность языка. Уважай нищие мысли» (Введенский 1993, 1: 196). В поэтическом мире Введенского это единственно подлинная реальность, в которой для человека «каждое мгновение открывается как новый, насыщенный мир», как это заметил Д. Токарев (2002: 109).

Раздробленный мир у Введенского приравнивается к сумасшедшему дому, равно как и хозяин сумасшедшего дома приравнивается к Богу, создавшему этот мир. Данное сходство подчеркивается мотивом «дряхлого окошка-зеркала» (Введенский 1993, 1: 196), в которое смотрит хозяин сумасшедшего дома и видит в нем троих, т. е. самого себя в трех ипостасях 9 .

7 Об этом писал М. Мейлах в давнем 1978 году: «самые свойства языка и являются важнейшим объектом критики Введенского: его универсальное сомнение переходит на форму высказывания как таковую» (Мейлах 1978: 389).

8 Кроме текста Я. Друскина «Звезда бессмыслицы», посвященного Некоторому количеству разговоров, обращаем внимание и на два текста А. Рымаря, в которых рассматриваются сюжет Разговоров как сюжет авторской мысли (Рымарь 2003: 152-157) и текстовые стратегии Введенского (Рымарь 2006: 316-328).

9 Введенский, бесспорно, учитывает символику троицы не только в христианском догмате (Отец, Сын, св. Дух), но и в языковых идиомах вроде «Бог любит троицу», а также в фольклорных формах, повествующих о трех братьях, на чем он строит сюжет пьески Потеи того же периода (1936-1937). 
Другими словами, зеркальный и зазеркальный миры тождественны друг другу, ворота и забор, разделяющие их, - условны, поэтому «никаких изменений не случается» (Там же). То, что «карета останавливается у ворот», та самая карета, в которую садится Чацкий в конце «Горя от ума» (в надежде покинуть сумасшедший мир, в котором он оказался с репутацией безумца), или же Поприщин в гоголевских «Записках сумасшедшего», чтобы попасть в вымышленную Испанию, а на самом деле в сумасшедший дом, свидетельствует о невозможности покинуть сумасшедший мир, поскольку другого мира не существует, и этот мир в нас. Поэтому гоголевская игра, в которой царская карета превращается в карету «скорой помощи» для главного героя, оказывается в основе мотива кареты в «Разговоре о сумасшедшем доме». Карета в каком-то смысле является метафорой последнего пути, предстающего в конечном итоге темой «Последнего разговора». Несостоятельность движения как возможности преодоления пространства, измерения времени и, в конце концов, нашего существования, демонстрируется в этом раздробленном, хаотическом мире остановкой кареты ${ }^{10}$. Это и есть мгновенье, уход от линии времени, амнезия. В этой точке открываются иные связи между человеком и миром, которые проявляются в сфере мышления и языка ${ }^{11}$. Не случайно Первый, Второй и Третий обмениваются мыслями не только в «Разговоре о сумасшедшем доме», но и в последующих разговорах. Не случайно «пошатнувшиеся» синтаксические, семантические, логические связи между словами обнаруживаются как первом, так и во всех других разговорах, вплоть до последнего.

В данном контексте представляются закономерными реплика-мысль Третьего об измельчании мира: «Нас осталось немного и нам осталось недолго» и требование-мысль Первого: «Пишите чисто. Пишите скучно. Пишите тучно. Пишите звучно» (Введенский 1993, 1: 196), связывающие воедино существование и процесс «чистого, скучного, тучного, звучного» писания. В отличие от Ивана Ивановича из пьесы Хармса Елизавета Бам (1927), свидетельствующего звучанием речи о собственном существовании: «говорю, чтобы быть»12, троица в Разговорах фактически провозглашает соглашательство с установленным окаменелым (не без отсылки к действующему соцреализму) каноном письма как возможность существования. По сути это не существование, ибо на всем лежит тень статичности, остановленного времени, отсутствия действия, ограниченности языка и мысли, о чем оповещают ремарки: «Уважай обстоятельства места. Уважай то что

10 Отметим здесь, что мотив кареты отсылает также к ходячей цитате из пьесы На дне Горького, к словам Сатина: «В карете прошлого никуда не уедешь», а также к известной поговорке «Счастье едет в карете, а с умом идет пешком».

11 В этом смысле карета и комната, как закрытые пространства, соотносятся с закрытым для чудесного сознанием, тогда как крыша, лодка и дорога предрасполагают наше сознание к потустороннему, тайному, неведомому.

12 Повторяя те же слова, Иван Иванович уже в следующей своей реплике добавляет: «Потом, думаю, уже поздно» (Хармс 1988: 187). 
случается. Но ничего не происходит. Уважай бедность языка. Уважай нищие мысли» (Введенский 1993, 1: 196) ${ }^{13}$.

Расшатанность мира передается давно кончившимися русскими стихами. Ими говорит Первый, сначала разделяя мир «мы» и мир сумасшедшего дома («он радостно ждет нас»), чтобы потом показать произошедшее раздвоение в «мы»: «Мы радостно ждем нас» (Введенский 1993, 1: 197). Эти безмолвные, мысленные, условные реплики, которыми обмениваются персонажи, в чем нас заверяют и закольцовывающие первый разговор ремарки «В карете ехали трое. Они обменивались мыслями», свидетельствуют о бессилии как человеческого ума что-либо понять, так и человеческого языка что-либо высказать. В данном контексте вспоминается трактат Я Друскина «Разговоры вестников» (1932), в котором философ-чинарь радикализирует феноменологический принцип эпохэ, редуцируя его до внутреннего молчания, вернее, до доречевого акта (ср. в фрагменте «О некотором волнении и некотором спокойствии»: «То - несказанное и неназванное, существующее и некоторое осуществление, не-то - все сказанное и возможное» (Друскин 1998а: 760))14. Введенский, как и философы чинари, питал повышенный интерес к несказанному, к существующему в «теперь», к освободившемуся от времени, он стремился поэтическим опытом разрешить загадку взаимосвязи человеческого бытия и речи ${ }^{15}$. Поэтому уже в самом названии «Разговор о сумасшедшем доме» присутствует субверсивный отказ от понятия «разговор», поддерживаемый оспариванием привычных языковых конструкций, самой возможности высказывания речью, в силу чего человеческий мир пребывает в молчании, становится немым ${ }^{16}$, тогда как мир

13 И. Кукуй в своем исследовании о поэтическом аскетизме Введенского выделяет три уровня в данной ремарке: «уровень локализованного действия, нейтрализованный тем, что на нем ничего не происходит; уровень слова, не могущего выразить невыразимое (отсюда язык беден); и уровень мыслей, которые не в состоянии осознать непроизошедшее и невыразимое»; при этом он триаду думать - понимать - говорить связывает со стадиями накопления — освоения — оформления (Кукуй 2020: 244, 245).

$14 \mathrm{O}$ феноменологической редукции в сочинениях Друскина см. в: Чернавин 2020: 73-82. См. также работу А. Меньшикова, посвященную размышлениям Друскина о времени, мгновении и вечности в контексте философии Розенцвейга, Бергсона и Гуссерля (Menshikov 2021: 252-266).

15 В «Серой тетради» (фрагмент «Глаголы») Введенский критикует наше представление о речи, о глаголе как части речи (обладает временем, текуч, подвижен), которое не совпадает с действительностью, с действиями, поскольку, например, название час может быть применено только к последнему часу перед смертью. Приводя в пример собственные стихи, где действия «нелогичны и бесполезны», Введенский рассуждает о том, что «глаголы на наших глазах доживают свой век», так как «в искусстве сюжет и действие исчезают», ибо «события не совпадают с временем» — «время съело события» (Введенский 1993, 2: 81). Другими словами, он предлагает искать иные связи между бытием и возможностями высказать его.

16 По этому поводу Я. Друскин пишет, что здесь «отрицается не содержание предложения, а вообще предложение, то есть высказывание предложения» и что вследствие аннигиляции предложений остается «ничего», которое «не просто “ничего”, а молчание: семиотическое молчание» (Друскин 1998b: 611). На это высказывание Я. Друскина впервые обратил внимание М. Мейлах в примечаниях к сочинениям Введенского (Мейлах 1993, 1: 272). 
природы периодически издает пронзительные звуки (лисицы «пищат», цветы «трещат» - Введенский 1993, 1: 197).

В отличие от первого «неразговора» ${ }^{17}$, противопоставляющего немой язык человека звучащему языку природы, второй «неразговор» об отсутствии поэзии раскрывает взаимосвязь природы и стихов, здешнего и загробного миров. Для Введенского важно подчеркнуть музыкальное, звучащее начало поэзии, поэтому Певец в «Разговоре об отсутствии поэзии» поет стихи на концерте, тем самым возвращая поэзию в лоно музыки, превращая слово в текучесть звучания ${ }^{18}$. В данном контексте и паузы, которые делает певец во время выступления (вместе с ритмическим появлением и исчезновением дивана ${ }^{19}$ в роли рефрена), следует понимать в музыкальном ключе, как часть звучащей песни. Однако суть выступления Певца сообщить об отсутствии поэтов, об их смерти, смерти музыкантов и певцов, о кладбище певцов, к которым в конечном итоге и сам он присоединяется. Поэтами названы лишь отошедшие в мир иной, унесшие с собой свои песни. Поэтому в земном мире нет больше музыки стихов, которая воспела бы природу, весь мир становится тусклым и скучным (отсюда и сравнение солнечной деятельности с наукой, которая в творчестве Введенского имеет исключительно отрицательное значение), гармония мироздания разрушается:

Дерево стоит без звука, Без почета ночь течет. Солнце тихо как наука Рощи скучные печет. $<\ldots>$ Тучи в небе ходят пышно. Кони бегают умно.

А стихов нигде не слышно, Все бесшумно все темно.

(Введенский 1993, 1: 197)

Оказывается, поэзия продолжает существовать там, где умершие поэты — под землей, но у них ее унаследовали другие представители живого мира, такие как черви, реки, звери:

17 «Разговор о сумасшедшем доме» и «Разговор об отсутствии поэзии» Я. Друскин называет «неразговорами», подчеркивая, что «в первом неразговоре - мудрое молчание», а во втором - «немудрое отсутствие музыки, стихов, звуков, противополагаемое музыке природы» (Друскин 1998b: 613).

18 О превращении слова в предмет и обратно, т. е. о значимости для Введенского превращения слова из одного состояния в другое, писал уже Я. Друскин (Друскин 1998b: 562). Это Друскин приравнивал к чуду, которого требовал Введенский от слова: «чтобы поэзия производила не только словесное чудо, но чтобы она была настоящим чудом» (Там же, 561).

19 М. Мейлах повторяющийся мотив дивана у Введенского связывает «с космосом и смертью», приводя в качестве примеров также сочинения «Кончина моря» и «Очевидец и крыса» (Мейлах 1993, 1: 243, 262). Добавим, что в этот ряд вписывается также мотив то порхающей, то взвивающейся в поднебесье, то бегущей Днепром «подушки» в пьеске Потеи, которую Введенский писал в те же 1936-1937 гг. 
Музыка в земле играет,

Червяки стихи поют.

Реки рифмы повторяют,

Звери звуки песен пьют.

(Введенский 1993, 1: 198)

В мире Введенского поэзия существует как одна из основополагающих космогонических стихий, ее не обязательно связывать с творчеством поэтов. Поэзия, по-видимому, является частью космического ритма (движения), который передается разными звуковыми реестрами. Поэтому носителями поэтического начала могут быть земля, червяки, реки, звери. Смерть певца в конце «Разговора об отсутствии поэзии» это доказала ${ }^{20}$. Последний «пиит» умер (вопреки упованиям Пушкина: «И славен буду я, доколь в подлунном мире /жив будет хоть один пиит»), но поэзия-стихия продолжает звучать другими поэтическими средствами, возвращаясь к звуку как таковому, к своему музыкальному началу. Звучание музыкальноритмических единиц во времени, причем в постгуманитарном мире, является одной из занимавших Введенского проблем.

Бесспорно, время - это главная тема Разговоров Введенского. Поэта интересуют возможности осознания времени, способы передачи мгновения, существования в «цисфинитном ноле», понимаемом Хармсом как чтото вроде бесконечного настоящего. Поскольку этот «цисфинитный ноль» «оказался на самом деле просто точкой перехода, совершенно безвременной и, соответственно, без собственного существования, зажатой между бесконечностью прошлого, которого уже нет, и бесконечностью будущего, которого еще нет» (Жаккар 2004: 77), Введенский обратился именно к этой точке безвременья, к пустоте или к вобравшей в себя всё, как единственной бесконечности и единственному цисфинитуму. Каждое мгновение он понимает как новую (у)летающую точку времени, существующую лишь для себя вследствие дробления времени, превратившегося в мерцание. В «Серой тетради» Введенский процесс восприятия раздробленного времени описывает следующими словами:

Потому что прежде чем прибавится новая секунда, исчезнет старая, это можно было бы изобразить так:

$$
\begin{aligned}
& \varnothing \varnothing \varnothing \varnothing \varnothing \varnothing \\
& \varnothing \varnothing \varnothing \varnothing 0
\end{aligned}
$$

Только нули должны быть не зачеркнуты, а стерты. <... Наш календарь устроен так, что мы не ощущаем новизны каждой секунды. А в тюрьме эта новизна каждой секунды, и в то же время ничтожность этой новизны стала мне ясной. (Введенский 1993, 2: 83)

20 Хотелось бы отметить, что певец Введенского во многом напоминает Импровизатора в «Египетских ночах» Пушкина. Их сближает, прежде всего, выступление перед публикой (Введенский отмечает, что двенадцать, двадцать, сорок человек сидело в комнате, чем по сути ставит под сомнение не только число присутствующих, но и необходимость перечислять их), а также вызов поэтам вдохновением, которое уводит их в иное время и пространство, приближает к смерти. 
С точки зрения Введенского нам мешают «названия минут, секунд, часов, дней, недель и месяцев», которые «отвлекают нас даже от нашего поверхностного понимания времени», поэтому он предлагает «с часов стереть цифры», «забыть ложные названии», чтобы время показало нам «свое тихое туловище, себя во весь рост» (Введенский 1993, 2: 80), ибо только тогда движение мыши (со всей ее мифологической значимостью) мы увидим новым, дробящимся, близким нулю, и это будет мерцание. Тогда и наш мир, и мы сами окажемся мерцающими ${ }^{21}$. Оттуда и ностальгическое стремление лирического субъекта к миру зверей, звезд, растений, птиц, насекомых, освобожденных от навязанного человеку понятия времени: «Мне жалко что я не зверь, Бегающий по синей дорожке $<. .>$ Мне жалко что я не звезда, Бегающая по небосводу <...> Еще есть у меня претензия, Что я не ковер, не гортензия <..> Мне жалко что я не орел, Перелетающий вершины и вершины <...> Мне страшно что я двигаюсь Не так как жуки жуки, Как бабочки и коляски И как жуки пауки» (Введенский 1993, 1: 183, 184). Чувство искаженности мира, возникающее под воздействием научно обусловленного понимания времени, так же, как и детерминированность человеческой жизни, в поэтической системе Введенского становятся поприщем, на котором ведется борьба за новое понимание времени.

Учитывая историю мышления о времени, начиная с апорий Зенона и философских систем Аристотеля, св. Августина, Николая Кузанского, вплоть до Эйнштейна, Введенский исследует существование предметов в природе через движение, т. е. как возникновение, непрерывное изменение и исчезновение. Введенский пытается понять характер времени, его неопределенность и бесконечность, которые неминуемо приводят мышление к противоречию. В этом смысле для него важную роль играли парадоксы в умозаключении, т. е. антиномии, сформулированные Зеноном в связи с движением, множеством, бесконечностью, временем, наиболее известными из которых являются «Ахилесс и черепаха», «Дихотомия» и «Летящая стрела»22. Парадоксальное мышление, демонстрирующее в апориях непрерывность и делимость, прерывность и неподвижность, приобрело новую жизнь в начале XX века в русской философии и литературе абсурда, по-

21 Однако в «Пять или шесть» Введенский противопоставляет неприемлемость человеком дробности пространства и времени («Не любит просто дробного Человек целый») осознанию того, что в пределах языка приходится говорить «приблизительно», поскольку «ничего точного все равно никогда не скажешь» (Введенский 1993, 1: 84). - Отметим здесь, что О. Ревзина в своей статье указывала на две черты «в обозначении языком временных понятий», которые угнетали Введенского: то, что «названия различных временных интервалов в языке обозначаются также, как самые разные понятия, никак не связанные с временем», и то, что «прошедшее и будущее изображаются как равные настоящему» (Ревзина 1978: 399).

22 В первых двух апориях Зенон показывает логические трудности при предпосылке о том, что время и пространство непрерывны и неограниченно делимы, в третьей, рассматривающей время как прерывное, составленное из точек-мгновений (в силу чего стрела предстает неподвижной, покоящейся в каждое мгновенье, а, значит, всегда), указывает также на логические трудности. 
этому и Введенский не мог не обратиться к парадоксу, сделав его главной составляющей своих литературных опытов. В этом смысле его интересовала судьба парадоксального мышления, которое под влиянием аристотелевской философии оказалось на задворках философии вплоть до XX века. Аристотель, оспаривая постулаты Зенона, в философском трактате Физика пытается дать свое определение категории времени. Он однозначно связывает время с движением и изменением (ср.: «мы вместе ощущаем и движение и время»), но не отождествляет их, поскольку движение может ускоряться или замедляться, тогда как время «непрерывно», «повсюду одно и то же», и потому что «время есть мера движения и нахождения [тела] в состоянии движения», причем для самого движения «“быть во времени” значит измеряться временем и самому ему и его бытию, ибо время вместе измеряет и движение и бытие движения, и находиться движению во времени значит именно то, что бытие его измеряется» (Аристотель 1981: 148, 151, 152). Так же как временем измеряется движение, числом (минут, часов, годов) измеряется время, и в этом определенном времени происходит то или иное событие, то или иное движение. Аристотель делает вывод, что не существует беспредельного пространства и времени, а существуют только определенное время и определенное пространство, что нет пустоты во времени и пространстве, но и пространства и времени нет вне мира, что мир вечен, так как движение непрерывно и вечно.

Если Введенскому и были чужды выводы Аристотеля, отрицавшие беспредельность пространства и времени, он не мог пройти мимо размышлений философа о потенциальности и действительности данных категорий (к тому же, сформулированными под влиянием апорий Зенона), о измеримости времени и движения, о мире как вечном движении. По-видимому, в споре с аристотелевским мышлением, определяющим все сущее с научным пристрастием, Введенский пишет «Разговор о воспоминании событий». Для «Разговора» выбраны по-аристотелевски конкретное время, конкретное пространство, конкретные тела, конкретное событие. И одновременно, Введенский этому конкретному, непрерывному миру противопоставляет парадоксальное мышление в духе Зенона, указывающее на бесконечность и прерывность в природе, единство и множественность мира. Размышления Введенского о единстве и множественности мира сформировались, возможно, и под влиянием тогда актуальной теории множеств Георга Кантора, в основе которой находилась неразрешимая антиномия Зенона о множественности бытия и конечности ${ }^{23}$. Также на Введенского могла повлиять и популярная в те годы теория «аритмологии» математика Николая Бугаева, построенная на идее прерывности - трещине с единичными интуитивными прозрениями, восходящими к Творцу, которая противопоставлялась аналитике - миросозерцанию, основанному на идее непрерывности и рассудочной деятельности, в котором не было места для свободы, твор-

23 Отметим здесь, что антиномиям времени у Введенского в контексте русской и западноевропейской философской мысли посвящена работа: Резвых 2014: 67-94. 
чества, веры. Аритмология со своим чувством трещины бытия, разрозненности мира, эсхатологического конца, соответствовала поэтическим воззрениям Введенского. В его мышлении присутствует антиномизм, непосредственно связанный с идей прерывности мира и бытия, который соединяет противоположности мира в виде мерцания (пульсации); это своеобразное диалектическое мышление, заключающее в себе постоянную смену ракурсов при непременной установке на мир как целое 24 .

$\mathrm{B}$ «Разговоре о воспоминании событий» участники мысленного спора Первый и Второй (по сути два явления одного) пытаются разрешить дилемму о произошедшем или не произошедшем событии - встрече собеседников, оказавшихся в одно время (вчерашнее, ушедшее) в двух близких точках А и Б в одном пространстве (комнате). Запертые в комнате-сознании они мысленно рассуждают (вернее, мысленно вспоминают спор с самого начала) о возможности вспомнить ушедшее время и представить закончившееся событие. Если Первый призывает в помощь точки А и Б, маркирующие присутствие их двоих на пространственной и временной линии, предметы-свидетели (картины, статуи, музыку), явления конюха на шкафе, леса цветов на комоде, фонтана под стулом, дворца под кроватью, расширяющих сугубо ограниченное комнатное пространство, лишь бы заставить память Второго вспомнить об их встрече, Второй отрицает как само событие их встречи, так и возможность измерить пространство и время точками и свидетелями, в существовании которых, к тому же, он сомневается («Ты не видел меня, я не видел тебя. О гнилых этих точках А и Б я даже говорить не хочу», «все молчат мои свидетели», «я сомневаюсь даже в существовании этих свидетелей» - Введенский 1993, 1: 199, 200). И Первый, и Второй одержимы «чувствами гнева, свирепости и любви к истине», оба они, вспоминая каждую реплику уже произошедшего спора о состоявшемся/несостоявшемся событии, стремятся припомнить и истину, однако их истина разная. Так, Первый уже усвоенными объективированными научными постулатами рассуждает о воспоминании и времени (том, что было), уверенный в произошедшей встрече, воспоминание о которой должно объединить участников события. Второй же в своих рассуждениях о воспоминании и времени отказывается от принятой научной логики, от мира вне своего субъекта, он говорит не о воспоминании, а о собственной амнезии, о временном забвении («я на время забыл что ты есть»), об отсутствии воспоминаний здесь и теперь, в это «мгновенье» («Я помню конюха, и могучий лес

24 Особое внимание вопросу антиномизма уделял Павел Флоренский в размышлениях о теодицее и антроподицее: антиномизм в теодицее он связывает с познанием Истины - центральной темой теодицеи (антиномизм Истины проявляется в рационально-дискурсивном восприятии вследствие расколотости человеческого разума; Истину можно постичь только в сочетании интуитивного и дискурсивного суждения, которые сами по себе бессильны постичь ее); преодоление антиномизма - суть антроподицеи Флоренского, и он предлагает человеку выход в иные координаты, такие как символ - онтологическая основа культуры и язык - символическое описание (см. более подробно в: Егорова 2009). 
цветов и журчащий фонтан, и широкий дворец, но где они, их нигде не видать»), он выдвигает различие как основополагающий субъективистский принцип («Ты был тобою, а я был собою» — Введенский 1993, 1: 199), раскрывающий иное, субъективное видение и иную, субъективную истину 25 . «Разговор о воспоминании событий» - это разговор о невозможности вспомнить событие и, одновременно, о возможности вспомнить речь, обсуждающую событие. Речь оказывается носителем нашего бытия во времени и пространстве, носителем нашей движущейся мысли. Говорящий в момент говорения выступает с позиций несомненной истины существования как самого себя, так и мира, и в этом смысле за речевым актом, за утверждающим «я говорю» скрывается другое утверждение - «я существую» ${ }^{26}$. Не событие, а речь оказалась «вещью», объединяющей Первого и Второго 27 . Восприятие события через речь изображает, на самом деле, речь как событие, ибо через нее совершается (о)познание мира, и тем самым гносеологический аспект вещи переносится из внешнего мира во внутренний мир человека. Это означает, что речи, произносимой в это мгновение, дано отменить границу между прошедшим временем и настоящим «теперь» и поместить прошедшее в точку «теперь».

Аналогично и «Разговор о картах» - это разговор о невозможности начать событие и, одновременно, о возможности начать разговор о готовности начать событие. Участники диалога, всю ночь восторженно отзываясь о картах, так и не начав игру, разговор заканчивают словами: «Вот и обвели ночь вокруг пальца (...). Вот она и кончилась» (Введенский 1993, 1: 201). Оказывается, все высказанное Первым, Вторым и Третьим служило мерой ночного времени, противостоянием ночи («Вот и обвели ночь вокруг пальца», «Вот она и кончилась» - Там же), уводящей жизнь из людей. Начало «Разговора о картах», приходящееся на четыре часа ночи, и конец его, совпадающий с концом ночи, соответствуют ночному бдению у гроба покойного, как следует из открывающих «Разговор» ремарок 28 ; иными словами, все, кто бодрствовал ночью, магической силой языка смог противо-

25 Поэтому Третий в конце этого разговора подытоживает: «Припомним конец вашего спора. Вы оба ничего не говорили. Все было так. Истина, как нумерация, прогуливалась вместе с вами. Что же было верного? Спор окончился. Я невероятно удивился» (Введенский 1993, 1: 200).

26 Рассматривая понятие «начала» в контексте времени («сейчас»), В. Гуревич в своей статье исследует философский план скрытых или не скрытых высказываний. В отличие от «я говорю», за которым обнаруживается «я существую», в декартовском «я мыслю, следовательно, я существую» В. Гуревич видит не результат логического вывода, а исходную посылку (Гуревич 2002: 59).

27 В данном контексте напрашивается мысль П. Флоренского об антиномии речи, которая должна быть и общей, и «от меня исходящей», подчиняющейся «малейшим тонкостям моей мысли, моей личности, и притом вот в этот, настоящий раз» (Флоренский 1990: 232).

28 Ср.: «Не все тут были из тех, кто бы мог быть, те кого не было, лежали, поглощенные тяжелыми болезнями у себя на кроватях, и подавленные семьи окружали их, рыдая и прижимая к глазам. Они были люди. Они были смертны. Что тут поделаешь. Если оглядеться вокруг, то и с нами будет то же самое» (Введенский 1993, 1: 200). 
стоять смерти и сохранить себе жизнь. Язык оказался неподвластен смерти, выше времени, единственной свидетельствующей о нас реальностью. Отсюда и радостное утверждение «вот и обвели ночь вокруг пальца», которое сопровождается троекратным ироничным «наука доказала» (Там же), чем Введенский фактически отказывает позитивистско-рационалистской науке в познании мира 29.

Спор в «Разговоре о воспоминании событий» наследует размышлениям древних. И Аристотель, и св. Августин человеческую жизнь характеризуют как исследование времени, соотнесенное с душой/духом, т. е. с воспоминаниями и переживаниями ${ }^{30}$. Для Аристотеля в Физике важно определить существует или не существует пустота, чтобы понимать движение и протекание времени в мире. При этом он считает нелепостью «считать пустотой точку», приравнивая ее к «теперь», которое «не есть часть» времени, так как время, одна часть которого была, и ее уже нет, а другая только будет, и ее еще нет, «не слагается из “теперь” (Аристотель 1981: 136, 145, 146) ${ }^{31}$.

29 Несомненно, отрицательное отношение Введенского к науке связано с современной ему наукой, не только отвергающей Бога, но и враждебно относящейся к нему и ко всему, созданному человеком во имя его. Занимаясь материальным миром, атеистическая наука не в состоянии познать мир, созданный Богом, более того, она пытается занять место Бога. Наука, отрицающая духовный мир, представляется Введенскому «скукой смертной» (ср.: «И печальную часть наук Постигает наш дух»; «И держал под мушку скуку Эту новую науку»; «Солнце тихо как наука Рощи скучные печет»; «Мы все исчадия наук И нами смертный час усвоен»; «Костями толстыми и голосом сочтетесь Вы ездоки науки в темноте»; «Сейчас пойду в университет Наук ученье изучать: Как из металла вынуть медь, Как электричество чинить, Как слово пишется медведь» - Введенский 1993, 1: 182, 124, 197, $172,146,177)$.

30 Ср. у Аристотеля: «Если же ничему другому не присуща способность счета, кроме души и разума души, то без души не может существовать время, в разве [лишь] то, что есть как бы субстрат времени; например, если существует без души движение, а с движением связаны «прежде» и «после», они же и есть время, поскольку подлежат счету» (Аристотель 1981: 157). Ср. у Августина: «В тебе, душа моя, измеряю я время. Избавь меня от бурных возражений в сумятице своих впечатлений. В тебе, говорю я, измеряю я время. Впечатление от проходящего мимо остается в тебе, и его-то, сейчас существующее, я измеряю, измеряя время. Вот где, следовательно, время или же времени я не измеряю» (Блаженный Августин 1992: 342). Рассуждая о категории времени у Аристотеля и Августина, Хайдеггер в книге «Понятие времени» подчеркивает, что у обоих авторов «время случается в человеческом вот-бытии», и «это бытие ведет счет времени», тогда как душа и дух «составляют "субстанцию” человеческого вот-бытия» (Хайдеггер 2021: 25-26), на основе чего Хайдеггер далее развивает свое видение времени.

31 Но тем не менее, согласно Аристотелю, «“Теперь” измеряет время, поскольку оно предшествует и следует; само же “теперь” в одном отношении тождественно, в другом нет: оно различно, поскольку оно всегда в ином и в ином времени (в этом и состоит его сущность как “теперь”), с другой стороны, “теперь” по субстрату тождественно» (Аристотель 1981: 149). - В. Бибихин в своем трактате «Точка» включается в диспут о времени, о «теперь», о точке, о линии; точку и «теперь» он называет неподвижными двигателями линии и времени: «Как же тогда возникает линия? и время? Так, что точка и момент «теперь»их неподвижный двигатель. Не совсем точно говорить поэтому, что движение точки создает линию. То есть именно движение точки создает линию, но в том смысле, что точка, сама не движущаяся, движет! Из-за того, что движущая способность точки не прекращается, т. е. всякую точку можно одновременно увидеть как начало и конец, собирающее и выпускающее, линия никогда не прекратится, она в принципе бесконечна. То же линиявремя. Допустим, время кончилось теперь, в это мгновение. Поскольку мгновение само 
Это «теперь», которое вне времени, вне линии времени, которое есть неподвижная точка, однако точка, которая собирает, втягивает в себя, и одновременно выбрасывает свою собранность из себя, оставаясь при этом неизменной, эта одна-единственная точка-«теперь» или точка-«мгновенье» остается главным интересом Введенского. Напомним, что о точке - однойединственной - пишет и Николай Кузанский. Для Кузанского точка — это «целостность» и «совершенство», которое «так свертывает в себе линию, как и линия развертывает точку», на основании чего он делает вывод, что и «движение есть развертывание покоя, поскольку в движении нет ничего кроме покоя» ${ }^{32}$, и «“"теперь” разворачивается во времени, поскольку во времени нет ничего, кроме “теперь”» (Кузанский 1979: 422).

Неподвижная точка-мгновенье и бесконечно дробимое время-движение всецело интересует Введенского. В «Разговоре о бегстве в комнате» Введенский «проверяет на прочность» общую теорию относительности он сталкивает две системы координат: одну, в которой комната не движется, а человек движется, и другую, в которой окружающий человека предметный мир (стол, стул, стена) движется вместе с ним. Бегать, двигаться значит убежать к Богу, «поскорей кончиться», динамичность имеет свое начало и конец, статичность - нет, поэтому человек - смертен, предметный мир - нет, поэтому трое бегающих утверждают: «Ничто никуда не убежало. Одни мы убегаем», понимая, что могут говорить о своем лишь «условно прочном существовании», чему и посвящен десятый, «Последний разговор» (Введенский 1993, 1: 203, 213). Условно прочное существование 33 подчеркивается и темой прощания Первого, Второго и Третьего с садом, с воздухом, с морем («И внимая стуку птиц, Звуку человечьих лиц И звериному рычанью, Встать побегать на прощанье»; «Здравствуй воздух мой сосед. Я обнимаю высоту. Я вижу Бога за версту»; «И понял: море это сад. Он музыкальными волнами Зовет меня и вас назад Побегать в комнате со снами» - Введенский 1993, 1: 202). Прощание с миром - это точка покоя или застывшего мгновения, в этой точке все одно, в ней море и сад, как

не движется, не меняется, не имеет длительности, оно уже собрало в себе конец всего, но этот конец длится именно только мгновение: конец истории не длится, не имеет длительности. Движение и история, не кончаясь в каждый момент, не имеют времени кончиться» (Бибихин 2017: 347).

32 Эту мысль он объясняет следующим образом: «Поскольку движение есть переход из одного состояния в другое - так как предмет, находясь в каждом данном состоянии, не движется, - постольку в движении нет ничего, кроме покоя. В самом деле, движение есть выход их данного состояния, и двигаться - значит отходить от чего-то одного, то есть к чему-то другому. Поэтому движение и есть переход от покоя к покою, так как оно оказывается не чем иным, как упорядоченным покоем, или состояниями покоя, последовательно упорядоченными» (Кузанский 1979: 422).

33 Условно прочному существованию посвящен также разговор о войне: в «Предпоследнем разговоре под названием один человек и война» Введенский тему войны развивает, соответствуя раздробленности времени и мира. Три ипостаси одного существа (1-й, 2-й, 3-й) обсуждают тему войны 1914 года в «суровой», «военной», «боевой» обстановке, где лицом к лицу «человек и земля», «человек и скала», «человек и война» (Введенский 1993, 1: 209), однако эта тема исследована нами в статье: Ичин 2014: 167-177. 
эсхатологические локусы, тождественны друг другу; развертывание этой точки в линию движения возвращает Первого, Второго и Третьего в комнату со снами и приводит их к мысли покончить с собой, что и является главной темой следующего «Разговора о непосредственном продолжении» 34 . Визуализация и вербализация смерти (через повешение, попытку утопиться в проруби и застрелиться) совершается в «полном покое», в неподвижности трех человек на крыше. Принятие смерти в полном покое соответствует нирваническому сознанию, освобожденному от страдания, что подтверждается как словом-эхом «умер», так и многократно повторяющимися ремарками «Они сидели на крыше в полном покое. Над ними летали воробьи» (Введенский 1993, 1: 203-205).

Собирание в точку оказалось обсессивной темой для Введенского с самого начала Разговоров. Так, в «Разговоре о сумасшедшем доме» в диалог вдруг прорывается реплика Третьего «нас осталось немного и нам осталось недолго» (Введенский 1993, 1: 196, 197). В «поясняющей мысли» в начале седьмого разговора — «Разговора о различных действиях» - дан первый намек на всеобую смерть, а не на умирание лишь трех участников предыдущих разговоров. Однако и в данном случае Введенский развивает не сюжет, заданный поясняющей мыслью, а сцену отплытия умерших на лодке Харона в царство теней, в частности, «в далекую Лету». Мотивы свечи, спичек, кислоты и побудительная интонация относительно «зажигания» света среди погасшего мира лишь подчеркивают эту идею. В данной связи несколько удивляет лишь разовое упоминание основной темы (один из персонажей задумался «об изображениях смерти, о ее чудачествах», однако «ничего <...> не мог понять» - Введенский 1993, 1: 212) в «Последнем разговоре», в котором частично суммируются предыдущие разговоры.

Оппозиция «мысль - действие», присутствующая в «Последнем разговоре», как собственно и в других разговорах, да и в других произведениях Введенского, зачастую нужна поэту, чтобы отменить ее и отождествить составляющие части, т. е. показать мысль как действие. Об этом убедительно писал Я. Друскин в тексте «Звезда бессмыслицы», взяв в качестве примера «Последний разговор» (Друскин 1998b: 333). Убедиться в собственном существовании позволяет лишь речевой акт о нашем существовании во времени, субституирующий действие, движение, событие (в «Разговоре о картах»). Поэтому и движение в десятом, «Последнем разговоре», лишь условно можно принять за движение. Это движение мысли об «условно прочном существовании», «об изображениях смерти, о ее чудачествах», «о чувстве жизни», «о карете, о баньщике, о стихах и о действиях» (Введенский 1993, 1: 212) 35 .

34 Теме самоубийства в «Разговоре о непосредственном продолжении» в сопоставлении с текстом «Где. Когда» посвящена статья Дж. Греппи Лукарелли (Греппи Лукарелли 2004: 83-87).

35 В ответ на отдельные мысли-реплики в «Последнем разговоре» А. Драгомощенко излагает буддистские мысли, предлагая таким образом свое прочтение Введенского и выстраивая своеобразный поэтический диалог (Драгомощенко 2011: 225-227). 
Введенский мысль «о чем-то», назовем это «предметной» мыслью, стремится превратить в размышление о том, что такое мысль сама по себе. Он пытается отгадать ее творческое начало, мир как «видимое» мысли, поскольку для него сам мыслительный процесс равнозначен сотворению мира. «Последний разговор», подытоживающий все предыдущие в Некотором количестве разговоров, есть прощание мысли с созданным ею миром. Происходит окончательное свертывание линии в точку, движения в покой, времени во «мгновение», языка в непонимание. Это уход в небытие по примеру немыслящего Бога, освободившегося от мысли в момент сотворения мира и ставшего абсолютным покоем. «Последний разговор» - это возвращение к бесконечному миру Божественного покоя.

\section{ЛИТЕРАТУРА}

Аристотель. «Физика». Аристотель. Сочинения: В 4 т. Т. 3. Москва: Мысль, 1981. «Беседа с В. Подорогой. К вопросу о мерцании мира». Логос 4 (1993): 139-150.

Бибихин Владимир. «Точка». Бибихин Владимир. Другое начало. Сакт-Петербург: Наука, 2017.

Блаженный Августин. Исповедь. Москва: Гендальф, 1992.

Введенский Александр. Полное собрание произведений. В 2 т. Москва: Гилея, 1993.

Греппи Лукарелли Джулия. «Александр Введенский. Самоубийство как “бегство к Богу”». Александр Введенский и русский авангард. Материалы международной научной конференции, посвященной 100 -летию со дня рождения А. Введенского. Санкт-Петербург: РГПУ им. А. И. Герцена, 2004: 83-87.

Гречко Валерий. «В поисках универсальной грамматики искусства: теория прибавочного элемента Казимира Малевича». Искусство супрематизма. Белград: Издание филологического факультета, 2012: 89-102.

Грыгар Моймыр. «Теория “прибавочного элемента” Казимира Малевича». Грыгар Моймыр. Знакотворчество. Семиотика русского авангарда. Санкт-Петербург: Академический проект, 2007: 301-324.

Драгомощенко Аркадий. «MESH». Новое литературное обозрение 108 (2011): 225-227.

Друскин Яков. «Разговоры вестников». «...Сборище друзей, оставленных судьбою», Л. Липавский. А. Введенский. Я. Друскин. Д. Хармс. Н. Олейников. «Чинари» в текстах, документах и исследованиях. Т. 1. Б. м., 1998а: 758-811.

Друскин Яков. «Звезда бессмыслицы». «...Сборище друзей, оставленных судьбою». Л. Липавский. А. Введенский. Я. Друскин. Д. Хармс. Н. Олейников. «Чинари» в текстах, документах и исследованиях. Т. 1. Б. м., 1998b: 549-642.

Друскин Яков. Дневники. Санкт-Петербург: Академический проект, 1999.

Друскин Яков. Дневники. 1963-1979, Санкт-Петербург: Академический проект, 2001.

Егорова Светлана. Антиномизм и диалектика в учении П. А. Флоренского. Автореф. дис. ... канд. филос. наук. Саратов, 2009.

Жаккар Жан-Филипп. «“Cisfinitum” и Смерть». Абсурд и вокруг. Москва: Языки славянской культуры, 2004: 75-91.

Иванов Вячеслав. «Заумь и театр абсурда у Хлебникова и обэриутов в свете современной лингвистической теории». Мир Велимира Хлебникова. Статьи. Исследования (19111998). Москва: Языки русской культуры, 2000: 263-278.

Ичин Корнелия. «Война со смыслом войны в творчестве Александра Введенского». Рycский авангард и война. Белград: Филологический факультет, 2014: 167-177.

Ичин Корнелия. «Казимир Малевич: экономия как пятое измерение». Логос 6 (2019): 215-228. Кузанский Николай. «Простец об уме». Кузанский Николай. Сочинения: В 2 т. Т. 1. Москва: Мысль, 1979: 385-444.

Кукуй Илья. «“Уважай нищие мысли”: поэтический аскетизм Александра Введенского». Изобилие и аскеза в русской литературе. Столкновения. переходы, совпадения. Под ред. Й. Херльта, К. Цандера. Москва: Новое литературное обозрение, 2020: 239-254. 
Липавский Леонид. «Разговоры». «...Сборище друзей, оставленных судьбою». Л. Липавский. А. Введенский. Я. Друскин. Д. Хармс. Н. Олейников. «Чинари» в текстах, документах и исследованиях. Т. 1. Б. м., 1998: 174-254.

Мейлах Михаил. «Семантический эксперимент в поэтической речи». Russian literature 4/VI (1978): 389-395.

Мейлах Михаил. «Примечания». Введенский Александр. Полное собрание произведений. В 2 т. Т. 1. Москва: Гилея, 1993: 223-284.

Ревзина Ольга. «Качественная и функциональная характеристика времени в поэзии А. И. Введенского». Russian Literature. 4/VI (1978): 397-401.

Резвых Татьяна. «Антиномии времени у А. Введенского». Логос. 3 (2014): 67-94.

Руднев Вадим. Энициклопедический словарь культуры ХХ века. Санкт-Петербург: Азбука. 2017a.

Руднев Вадим. Против Истины. Москва - Санкт-Петербург: Добросвет, 2017b.

Рымарь Андрей. «Сюжет переживания в "Некотором количестве разговоров" А. Введенского». Филологические записки. Вып. 20. Воронеж, 2003: 152-157.

Рымарь Андрей. «Текстовые стратегии Александра Введенского на примере анализа "Некоторого количества разговоров"». Вестник Самарской гуманитарной академии. Вып. 1 (4), 2006. Филология, философия. Самара, 2006: 316-328.

Татаринова Ольга. «Принципы апофатической поэтики в творчестве А. Введенского». Теория и практика общественного развития 7 (2011): 357-359.

Токарев Дмитрий. Курс на худшее: абсурд как категория текста у Даниила Хармса и Сэмюэля Беккета. Москва: Новое литературное обозрение, 2002.

Фещенко Владимир. Лаборатория Логоса. Языковой эксперимент в авангардном творчестве. Москва: Языки славянских культур, 2009.

Флоренский Павел. «Мысль и язык». Флоренский Павел. У водоразделов мысли. Т. 2. Москва: Правда, 1990: 109-338.

Хайдеггер Мартин. Понятие времени. Санкт-Петербург: Владимир Даль, 2021.

Хармс Даниил. «Елизавета Бам». Хармс Даниил. Полет в небеса. Стихи. Проза. Драмыл. Письма. Ленинград: Советский писатель (Ленинградское отделение), 1988: 175-205.

Чернавин Георгий. «“Редукция, если она есть”: феноменологическая фантастика Якова Друскина». Вестник русской христианской гуманитарной академии 1 (2020): 73-82.

Menshikov Andrey. "Time, Moment, Eternity: Hieroglyphs and Meditations in Yakov Druskin's Philosophy”. Changing, Societies \& Personalities 2 (2021): 252-266.

Milner-Gulland Robin. “'Kovarnye stikhi': Notes on Daniil Kharms and Aleksandr Vvedensky”. Essays in Poetics 1 (1984).

Roberts Graham. The last Soviet Avant-garde. OBERIU - fact, fiction, metafiction. Cambridge: Cambridge University Press, 1997.

\section{REFERENCES}

Aristotel'. «Fizika». Aristotel'. Sochineniya: V 4 t. T. 3. Moskva: Mysl', 1981.

«Beseda s V. Podorogoj. K voprosu o mercanii mira». Logos 4 (1993): 139-150.

Bibihin Vladimir. «Tochka». Bibihin Vladimir. Drugoe nachalo. Sakt-Peterburg: Nauka, 2017.

Blazhennyj Avgustin. Ispoved'. Moskva: Gendal'f, 1992.

Chernavin Georgij. «"Redukciya, esli ona est"”: fenomenologicheskaya fantastika Yakova Druskina». Vestnik russkoj hristianskoj gumanitarnoj akademii 1 (2020): 73-82.

Dragomoshchenko Arkadij. «MESH». Novoe literaturnoe obozrenie 108 (2011): 225-227.

Druskin Yakov. «Razgovory vestnikov». «...Sborishche druzej, ostavlennyh sud'boyu». L. Lipavskij. A. Vvedenskij. Ya. Druskin. D. Harms. N. Olejnikov. «Chinari» v tekstah, dokumentah $\mathrm{i}$ issledovaniyah. T. 1. B. m., 1998a: 758-811.

Druskin Yakov. «Zvezda bessmyslicy». “...Sborishche druzej, ostavlennyh sud'boyu”. L. Lipavskij. A. Vvedenskij. Ya. Druskin. D. Harms. N. Olejnikov. "Chinari”" v tekstah, dokumentah i issledovaniyah. T. 1. B. m., 1998b: 549-642.

Druskin Yakov. Dnevniki. Sankt-Peterburg: Akademicheskij proekt., 1999.

Druskin Yakov, Dnevniki. 1963-1979, Sankt-Peterburg: Akademicheskij proekt, 2001.

Egorova Svetlana. Antinomizm i dialektika v uchenii P. A. Florenskogo. Avtoref. diss. ... kand. filos. nauk. Saratov, 2009. 
Feshchenko Vladimir. Laboratoriya Logosa. YAzykovoj eksperiment v avangardnom tvorchestve. Moskva: Yazyki slavyanskih kul'tur, 2009.

Florenskij Pavel. «Mysl' i yazyk». Florenskij Pavel. U vodorazdelov mysli. T. 2. Moskva: Pravda, 1990: 109-338.

Greppi Lukarelli Dzhuliya. "Aleksandr Vvedenskij. Samoubijstvo kak "begstvo k Bogu"». Aleksandr Vvedenskij i russkij avangard. Materialy mezhdunarodnoj nauchnoj konferencii, posvyashchennoj 100-letiyu so dnya rozhdeniya A. Vvedenskogo. Sankt-Peterburg: RGPU im. A. I. Gercena, 2004: 83-87.

Grechko Valerij. «V poiskah universal'noj grammatiki iskusstva: teoriya pribavochnogo elementa Kazimira Malevicha». Iskusstvo suprematizma. Belgrad: Izdanie filologicheskogo fakul'teta, 2012: 89-102.

Grygar Mojmyr. «Teoriya "pribavochnogo elementa" Kazimira Malevicha». Grygar Mojmyr. Znakotvorchestvo. Semiotika russkogo avangarda. Sankt-Peterburg: Akademicheskij proekt, 2007: 301-324.

Hajdegger Martin. Ponyatie vremeni. Sankt-Peterburg: Vladimir Dal', 2021.

Harms Daniil. «Elizaveta Bam». Harms Daniil. Polet v nebesa. Stihi. Proza. Dramy. Pis'ma. Leningrad: Sovetskij pisatel' (Leningradskoe otdelenie), 1988: 175-205.

Ichin Korneliya. «Vojna so smyslom vojny v tvorchestve Aleksandra Vvedenskogo». Russkij avangard i vojna. Belgrad: Filologicheskij fakul'tet, 2014: 167-177.

Ichin Korneliya. «Kazimir Malevich: ekonomiya kak pyatoe izmerenie». Logos 6 (2019): 215-228.

Ivanov Vyacheslav. «Zaum' i teatr absurda u Hlebnikova i oberiutov v svete sovremennoj lingvisticheskoj teorii». Mir Velimira Hlebnikova. Stat'i. Issledovaniya (1911-1998). Moskva: Yazyki russkoj kul'tury, 2000: 263-278.

Kukuj Il'ya. «"Uvazhaj nishchie mysli”: poeticheskij asketizm Aleksandra Vvedenskogo». Izobilie i askeza v russkoj literature. Stolknoveniya. perekhody, sovpadeniya. Pod red. J. Herl'ta, K. Candera. Moskva: Novoe literaturnoe obozrenie, 2020: 239-254.

Kuzanskij Nikolaj. «Prostec ob ume». Kuzanskij Nikolaj. Sochineniya. V 2 t. T. 1. Moskva: Mysl’, 1979: $385-444$.

Lipavskij Leonid. «Razgovory». «...Sborishche druzej, ostavlennyh sud'boyu». L. Lipavskij. A. Vvedenskij. Ya. Druskin. D. Harms. N. Olejnikov. «Chinari» v tekstah, dokumentah i issledovaniyah. T. 1. B. m., 1998: 174-254.

Mejlah Mihail. «Semanticheskij eksperiment v poeticheskoj rechi». Russian literature 4/VI (1978): 389-395.

Mejlah Mihail. «Primechaniya». Vvedenskij Aleksandr. Polnoe sobranie proizvedenij. V 2 t. T. 1. Moskva: Gileya, 1993: 223-284.

Menshikov Andrey. "Time, Moment, Eternity: Hieroglyphs and Meditations in Yakov Druskin's Philosophy". Changing, Societies \& Personalities 2 (2021): 252-266.

Milner-Gulland Robin. “'Kovarnye stikhi': Notes on Daniil Kharms and Aleksandr Vvedensky”. Essays in Poetics 1 (1984).

Revzina Ol'ga. «Kachestvennaya i funkcional'naya harakteristika vremeni v poezii A. I. Vvedenskogo». Russian Literature 4/VI (1978): 397-401.

Rezvyh Tat'yana. «Antinomii vremeni u A. Vvedenskogo». Logos. 3 (2014): 67-94.

Roberts Graham. The last Soviet Avant-garde. OBERIU - fact, fiction, metafiction. Cambridge: Cambridge University Press, 1997.

Rudnev Vadim. Enciklopedicheskij slovar' kul'tury XX veka. Sankt-Peterburg: Azbuka. 2017a.

Rudnev Vadim. Protiv Istiny. Moskva - Sankt-Peterburg: Dobrosvet, 2017b.

Rymar' Andrej. «Syuzhet perezhivaniya v "Nekotorom kolichestve razgovorov" A. Vvedenskogo». Filologicheskie zapiski. Vyp. 20. Voronezh, 2003: 152-157.

Rymar' Andrej. «Tekstovye strategii Aleksandra Vvedenskogo na primere analiza "Nekotorogo kolichestva razgovorov"». Vestnik Samarskoj gumanitarnoj akademii. Vyp.1 (4), 2006. Filologiya, filosofiya. Samara, 2006: 316-328.

Tatarinova Ol'ga. «Principy apofaticheskoj poetiki v tvorchestve A. Vvedenskogo». Teoriya i praktika obshchestvennogo razvitiya 7 (2011): 357-359.

Tokarev Dmitrij. Kurs na hudshee: absurd kak kategoriya teksta u Daniila Harmsa i Semyuelya Bekketa. Moskva: Novoe literaturnoe obozrenie, 2002.

Vvedenskij Aleksandr. Polnoe sobranie proizvedenij. V 2 t. Moskva: Gileya, 1993.

Zhakkar Zhan-Filipp. "“Cisfinitum” i Smert'». Absurd i vokrug. Moskva: Yazyki slavyanskoj kul'tury, 2004: 75-91. 
Корнелија Ичин

ПРОЛЕГОМЕНЕ УЗ ОДРЕЋЕНУ КОЛИЧИНУ РАЗГОВОРА А. ВЕДЕНСКОГ

\section{Резиме}

У раду се истражује логика мышљења Веденског, који одбацује Аристотелову логику и изражава сумњу у могућности језичког дефинисања постојања. «Песничка критика разума» Веденског показана је на примеру Одређене количине разг̄овора, где се открива дубља повезаност између речи од оне која је задата логичким мишљењем. Представљен је нови модел комуникације, који није изграђен на односу субјекат - субјекат, већ на односу субјекта према објектима земаљског света, као што су звезде, камење, планине, море, рибе, птице, инсекти, дрвеће.

Кључне речи: А. Веденски, Одређена количина разг̄овора, критика силогизма, неразумевање, време. 